\title{
Glycine Turnover Rates and Pool Sizes in Neonates as Determined by Gas Chromatography- Mass Spectrometry and Nitrogen 15
}

\author{
J. AMIR. S. H. REISNER, AND A. LAPIDOT \\ Sotope Department, the Weizmann Institute of Science, Rehovot, Israel, and Department of Neonatologi: Beilinson \\ Medical Center. Petah Tikva. Israel
}

\begin{abstract}
Summary
This report makes use of a recent developed method with stable isotope and gas chromatography-mass spectrometry to determine the disappearance of labeled amino acids from plasma samples after iv administration of a single dose $(93.3-\mu$ moles $/ \mathrm{kg}$ body weight) of $\left.\right|^{15} \mathrm{~N} /$ glycine $(92 \% \mathrm{~N})$ in neonates. $\left|{ }^{15} \mathrm{~N}\right| \mathrm{Glycine}$ measurements were studied three times in each of six preterm infants at different gestational age and twice in two full-term infants. The first study was carried out in all infants 5 to $32 \mathrm{hr}$ after delivery, the second study was performed on the third day of life, and the third study, included only the preterm infants, was at the age of 25 to 29 days. The isotope disappearance curves were linear within the first hr after $\mid{ }^{15} \mathrm{~N} / g$ lycine administration and represent mainly the hepatic uptake of glycine from the extracellular pool. The volume of glycine pool varied from the day of birth to 4 wk of life. Turnover rate constants of glycine ranging from 1.35 to $2.19 \mathrm{hr}^{-1}$ were observed in preterm and term infants during the first $32 \mathrm{hr}$. Significant increases in turnover rate constants were noted on the third day of life in most infants. At 3 to 4 wk of life, statistically significant differences in pool size and turnover rate constants were obtained. An increase of 2 - to 3 -fold in turnover rate constants was observed as compared to day of birth. Pool sizes declined by $50 \%$, but the resulted fluxes remained almost unchanged during the neonatal period. At the age of 3 to 4 wk, all these infants showed similar kinetic data as in adults.
\end{abstract}

\section{Speculation}

The kinetic study of individual amino acids during the first month of life in newborn infants might help in determining the correct usage of intravenous amino-acids during this period in infants requiring parenteral nutrition.

In view of the increasing use of parenteral nutrition in premature and sick newborn infants, knowledge of the metabolism of infused amino acids is most important.

There are some known time-dependent changes in plasma amino acid levels during the first $10 \mathrm{hr}$ and 3 days of life $(2,8,24$, $34)$ and changes according to dietary intake $(23,32,33,35,40)$, but there are relatively few studies on the dynamic aspects of amino acid metabolism in the newborn $(29,30)$. Amino acid tracer studies in humans have provided a great deal of information on whole-body protein metabolism $(25,41,46,47)$. but practically no estimates of the rate of uptake and metabolism of individual amino acids. This is because it has not been technically possible to measure stable isotope enrichments of amino acids in small samples of plasma, and measurements have instead been made on the excretion of the isotope in the form of uriary urea. Inasmuch as the equilibration of labeled amino nitrogen with the body nitrogen is fast compared to formation and excretion of urea. information is obtained on the behavior of metabolic nitrogen pool rather than on individual amino acids. The uptake of the amino acids into tissue is completed long before the conversion of the amino acids to the excretion products.

It has long been recognized that the rate of disappearance of a labeled amino acid from the circulation in the first 5 to $20 \mathrm{~min}$ after the IV administration reflects the transport of circulating amino acids from the extravascular-extracellular space to the intracellular pool (25). Radiolabeled amino acids were used in the early 1960's to follow the removal from circulation of glycine in children (27). This method was not further applied in studies in children due to health hazards associated with the use of radioactive tracers.

A rapid, convenient noninvasive stable isotope (and gas chromatography-mass spectrometry) method capable of measuring the rate of uptake of amino acid and the pools of extracellular amino acid in whole body was recently developed $(14,15,18,25)$ and applied to studies in humans $(17,19,20)$.

\section{MATERIALS AND METHODS}

\section{MATLRIAI.}

[ $\left.{ }^{15} \mathrm{~N}\right] \mathrm{NH}_{4} \mathrm{Cl}(92 \%$ " $\mathrm{N}$ enriched) by the method of Schoenheimer and Ratner (9) recrystalized from ethanol and further purified by sublimation. Each preparation was at least 99?; pure. measured by amino acid analizer, mass spectrometry, and thin-layer chromatography. The $\left[{ }^{15} \mathrm{~N}\right]$ glycine preparation was pyrogen-free by standard rabbit body temperature measurement. Standard solutions of the purified $\left[{ }^{15} \mathrm{~N}\right]$ glycine $(93.3 \mu$ moles $/ \mathrm{ml})$ in distilled water, sterilized by passage through a Millipore filter (GSWP 02500 ), autocalved, and administered as a single dose of 93.3 $\mu$ moles $/ \mathrm{kg}$ body weight, dissolved in water.

\section{SUBJE(TS ANI) I)IET}

The subjects included six preterm and two full-term infants. All the infants had Apgar scores at 1 and $5 \mathrm{~min}$ between 7 to 10 . Seven of the infants were born by vaginal vertex deliveries and one by cesarean section. Gestational age was assessed by the maternal obstetrical history, the Dubowitz scoring system (3). and examination of the anterior vascular capsule of the lens in the infants at less than $34 \mathrm{wk}$ (13). All infants were appropriate for gestational age (45) and were well at the time of the studies. Pertinent biographic data of the infants is summarized in Table 1. All of the preterm infants and one of the term infants received no PO feedings before the first study. The preterm infants received only IV glucose in amounts between 5.2 to $5.7 \mathrm{mg} / \mathrm{min} / \mathrm{kg}$. The other term infant had two feeds before the study. In this infant as well as in those in the second and third studies, tests were performed 3 to $4 \mathrm{hr}$ after a feeding. Two mothers (of $H$. A. and S. F. and S. S.) received Celestone Chronodose (betametazone disodium phosphate and betametazone acetate; Schering Co. Ken- 
Table 1. Subjects' biographic data and time schedule

\begin{tabular}{|c|c|c|c|c|c|c|c|}
\hline \multirow{2}{*}{ Subjects } & \multirow[b]{2}{*}{$\begin{array}{c}\text { Gestational age } \\
\text { (wk) }\end{array}$} & \multicolumn{3}{|c|}{ Age and wt at time of investigation } & \multicolumn{3}{|c|}{ Feeding regimes } \\
\hline & & $\begin{array}{l}\text { First study } \\
\text { (hr) }\end{array}$ & $\begin{array}{l}\text { Second study } \\
\text { (hr) }\end{array}$ & $\begin{array}{l}\text { Third study } \\
\text { (day) }\end{array}$ & First study & Second study & Third study \\
\hline S. L. & 29 & $10(1140)^{1}$ & $79(1040)$ & $25(1600)$ & $175(\mathrm{gl})^{2}$ & $670(\mathrm{gl})$ & $185(\mathrm{sm})$ \\
\hline H. A. & 31 & $9(1400)$ & $80(1300)$ & $29(23() 0)$ & $343(\mathrm{gl})$ & $\begin{array}{l}166(\mathrm{gl}) \\
110(\mathrm{sm})\end{array}$ & $174(\mathrm{sm})$ \\
\hline S. F. & 33 & $5(1600)$ & $89(1500)$ & $29(2100)$ & $333(\mathrm{gl})$ & $160(\mathrm{sm})$ & $171(\mathrm{sm})$ \\
\hline S. S. & 33 & $5(1770)$ & $89(1600)$ & $29(2400)$ & $333(\mathrm{gl})$ & $165(\mathrm{sm})$ & $200(\mathrm{sm})$ \\
\hline N. S. & 34 & $17(1600)$ & $90(1600)$ & $29(2400)$ & $312(\mathrm{gl})$ & $135(\mathrm{sm})$ & $200(\mathrm{sm})$ \\
\hline A. D. & 35 & $8(1830)$ & $75(1720)$ & $26(220(0)$ & $328(\mathrm{gl})$ & $185(\mathrm{sm})$ & $240(\mathrm{sm})$ \\
\hline B. $\mathbf{M}^{3}$ & 39 & $13(2550)$ & $88(2420)$ & & & $130(\mathrm{~cm})$ & \\
\hline Z. A. & 41 & $32(2 \times 30)$ & $73(2700)$ & & $62(\mathrm{~cm})$ & $133(\mathrm{~cm})$ & \\
\hline
\end{tabular}

' Numbers in parentheses, weights at time of investigation.

${ }^{2}$ gl, glucose IV (mg/kg/hr); sm, similac PO (ml/kg/day); $\mathrm{cm}, 66 \%$ cow's milk in water PO (ml/kg/day).

${ }^{3}$ No feeding before first study.

ilworth, NJ) and Yutopar (ritodrin: Philips-Duphar B.V.. Amsterdam, Netherlands) before delivery.

The nature of the investigation was explained to each mother, and babies were studied only after informed consent was obtained. The study received the approval of the Human Studies Committee of the Beilinson Medical Center, Petah Tikva.

\section{EXPERIMENTAL DESIGiN}

$\left[{ }^{1.5} \mathrm{~N}\right]$ Glycine kinetic measurements were studied three times in each preterm infant and twice in the full-term infants. Time schedules are detailed in Table 1. The first study was carried out in all infants between 5 and $17 \mathrm{hr}$ after delivery, except in $\mathrm{Z}$. A.. a full-term infant in whom the $\left[{ }^{15} \mathrm{~N} \mid\right.$ glycine study was performed only at $32 \mathrm{hr}$ of age. The second study was performed on the third day of life ( 73 to $90 \mathrm{hr}$ ). The third study, which included only the preterm infants, was at the age of 25 to 29 days.

\section{PROTOCOL.}

A total of 22 studies were carried out on the 8 infants. An indwelling catheter was inserted into a peripheral vein for blood sampling. A single dose of $\left[{ }^{1.5} \mathrm{~N}\right]$ glycine $\left(92 \%{ }^{1.5} \mathrm{~N}, 93.3 \mu\right.$ moles $/ \mathrm{kg}$ body weight dissolved in 1 to $3 \mathrm{ml}$ water) was administered via another peripheral vein over 10 to $20 \mathrm{sec}$. Blood samples were taken before (time zero) and at intervals of $5 \mathrm{~min}$ after IV administration. Between each sampling. the indwelling catheter was flushed with saline. Blood samples $(0.8$ to $\mathrm{I} \mathrm{ml})$ were collected in tubes containing $0.1 \mathrm{ml}$ of $3.7 \%$ citrate solution and were iced before centrifugation. Urine was collected 1 to $3 \mathrm{hr}$ before $\left[{ }^{15} \mathrm{~N}\right]$ glycine administration and during the first $2 \mathrm{hr}$ after administration.

\section{SAMPLE PREPARATION}

Immediately upon completion of the collection of the blood samples, plasma was isolated. The plasma proteins were precipitated with equal volume of $10 \%$ irichloroacetic acid. The supernatant was removed and extracted with five volumes of ether and was ready for derivatization.

\section{('AAS-CHROMATOGRAPHY MASS-SPECTROMETRY AND DATA ANALYSIS}

The plasma amino acids obtained after delipidization were esterified for analysis by gas chromatography to either $n$-trifluoroacetyl or $n$-pentafluoropropionyl $n$-butyl derivatives. The amino acid mixture $(0.1$ - to $0.3-\mu$ mole aliquots) were separated by standard methods $(7,36,38)$ using a Varian gas chromatography coupled by a metal splitter to a Finnigan quadropole mass spectrometer (model 1015) and computer-averaging memory oscilloscope (19).

The isotope disappearance curves were linear in all studies carried out. Hence, it was assumed $(15,26)$ that within the first hr after administration of the labeled amino acid, the disappearance of the $\left[{ }^{15} \mathrm{~N}\right]$ glycine from the circulation can be described by unidirectional irreversible flux of glycine through a single compartment with a pool size $(A)$, unidirectional influx $(F)$, and efflux (E). The isotope enrichment (I) at time (t) following a single dose $\left(\mathrm{W}, \mu\right.$ equivalents ${ }^{15} \mathrm{~N}$ ) of labeled compound is: $I_{1}=[\mathrm{W} /(\mathrm{A}+\mathrm{W})]$ $\exp (k t) \times 100$, where $k$ is the first-order rate constant for efflux $(E=k . W)$. The turnover rate constant of glycine in the pool is represented by $k$ ( $\left.h r^{~ '}\right)$, which is obtained directly from the slope of the isotope enrichment time decay curve. The pool size, A $\left(\mu\right.$ mole $/ 100 \mathrm{~g}$. body weight), is $\left.\mathrm{A}=\mathrm{d} \times\left[\mathrm{I}_{\mathrm{d}} / \mathrm{I}_{11}\right)-1\right]$, where $\mathrm{d}$ is the dose of labeled glycine $(\mu$ mole $/ 100 \mathrm{~g}$ body weight $) . I_{\mathrm{d}}$ is the isotope enrichment of the administered glycine, and $I_{10}$ is the isotope enrichment of plasma glycine extrapolated to time zero. The errors in the slope and intercept were evaluated by standard statistical methods $(9,21)$. It was found $(17,19,26)$ that the joint confidence region map (slope versus intercept) is a powerful and accurate method for visually evaluating the significance of differences in pool sizes, rate constants, and flux in a population of humans or an individual human in different metabolic states. Furthermore, certain areas on the joint confidence region maps can be associated with different metabolic and pathological states $(17,19,26)$.

\section{MEASUREMENT OF PI.ASMA (II.YCINE LIVVELS}

A colormetric-fluorometric method (37) was used to determine the plasma glycine levels in each blood sample with a volume of $0.1 \mathrm{cc}$ of deproteinized plasma. Measurements were carried out using an Aminco-Bowman Spectrophotofluorometer (American Instrument Co. Inc., Silver Spring, MD).

\section{DETERMINATION OF GI.YCINE CONCENTRATIONS IN URINI:}

The method described above was used to measure glycine in urine before and after $\left[{ }^{15} \mathrm{~N}\right]$ glycine administration.

\section{RESULTS}

\section{PLASMA (;IYYCINE I.EVEIS}

Plasma glycine concentrations were determined in each blood sample before and after $\left[{ }^{15} \mathrm{~N}\right]$ glycine administered into the infants. As seen in Figure 1, during the first 3 to $5 \mathrm{~min}$ after $\left[{ }^{16} \mathrm{~N}\right]$ glycine administration, glycine levels increase about 10 to $20 \%$ above the basal level. Significant differences in plasma glycine concentration were noted between the day of birth and the third day of life (Fig. 2 ) which corresponds to the findings of others (2, 24, 34).

\section{URINE: GI.YCINE LEVEIS}

Table 2 summarizes the glycine concentrations in urine before and during the first and the second $\left[^{16} \mathrm{~N} / g\right.$ lycine administration in 


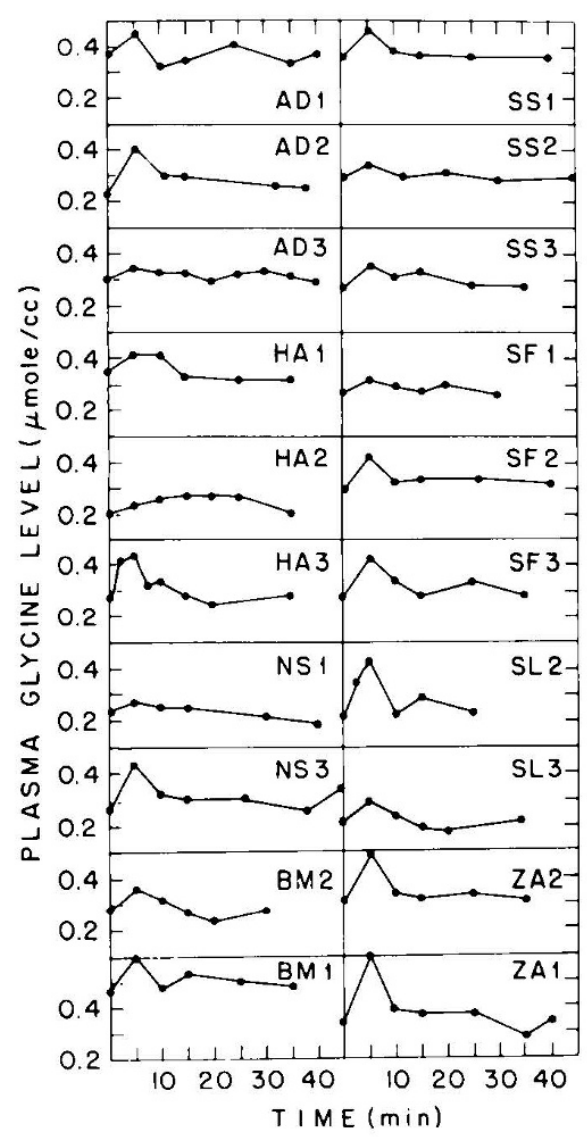

Fig. 1. Plasma glycine levels after the injection of $\left[{ }^{15} \mathrm{~N}\right]$ glycine $(9.3$ $\mu$ moles $/ 100 \mathrm{~g}$ body weight) in all infants studied at different ages. $I$, day of birth; 2, third day of life; 3,3 to 4 wk old.

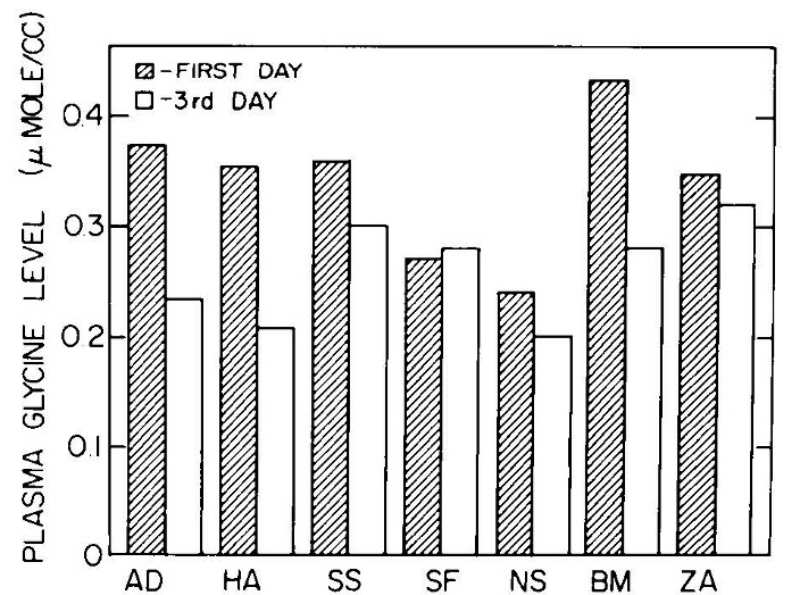

Fig. 2. Plasma glycine levels of infants on day of birth and third day of life.

two preterm infants (A. D. and S. L.). The amount of glycine excreted in urine after glycine administration did not exceed $1.9 \%$ of the injected glycine dose and in most cases less than $1 \%$. There is no indication that glycine could leak out as a result of a load of glycine.

DYNAMIC PARAMETER OF CII.YCINE.

$\left[{ }^{15} \mathrm{~N}\right]$ Glycine measurements were studied three times in each of the six preterm infants and twice in the two term infants. The isotope disappearance curves (Fig. 3) were linear within the first $\mathrm{hr}$ following $\left[{ }^{15} \mathrm{~N}\right]$ glycine administration. Mixing with the miscible pool is completed within $5 \mathrm{~min}$ in most cases, allowing sufficient time for the measurement to be made before the isotope enrichments fall below the range which could not be measured. Delayed mixing does not appear to introduce errors into the determination of pool sizes from the zero time intercepts. The slopes and intercepts of the least squares lines describing the isotope enrichment time decay curves and the corresponding pool sizes and turnover rate constants are given in the joint confidence region map (Fig. 4: Table 3).

\section{EXTRACELLULAR POOI. SIZI:}

Statistically significant $(P<0.01)$ high glycine pool sizes ranging from 14.7 to $20.6 \mu$ moles $/ 100 \mathrm{~g}$ body weight were noted in all infants studied on the day of birth when compared with one month of life (Table 4 : values of 7.7 to $11.5 \mu$ moles/ $100 \mathrm{~g}$ body weight). A decrease in pool sizes was observed already on the third day of life in the preterm and term infants.

The volume of glycine pool (pool size: plasma glycine level) obtained in this study varied from day of birth to 3 days and 3 to $4 \mathrm{wk}$ of life as depicted in Figure 5: 25 to $40 \%$ decline in pool volumes were observed in preterm infants at 3 to 4 wk of life. Mean values of $530 \mathrm{ml} / \mathrm{kg}$ body weight at day of birth and 360 $\mathrm{ml} / \mathrm{kg}$ body weight at the age of 3 to $4 \mathrm{wk}$ are compatible with the extracellular volumes at this age $(5,16)$.

\section{RATE CONSTANTS OF (ILYCINE DISAPPEARANC $\mathrm{E}$ :}

Turnover rate constants of glycine ranging from 1.35 to 2.19 $\mathrm{hr}^{-1}$ were observed in preterm and term infants on day of birth (Table 3; Fig. 4).

Significant increases $(P<0.01)$ in turnover rate constants were noted on the third day of life in most infants. In the most preterm infants, S. L. and H. A., turnover rate constants on the third day of life did not change significantly from day of birth. whereas at 3 to $4 \mathrm{wk}$ of life, the turnover rate constants of glycine increased significantly $(P<0.01)$. The turnover rate constants at 3 to $4 \mathrm{wk}$ of life range from 3.4 to $5.0 \mathrm{hr}^{-1}$, an increase of 2 - to 3 -fold as compared to day of birth. Glycine fluxes remained unchanged in most cases studied during the first month of life.

Table 4 and Figure 6 summarize the variation of plasma glycine dynamic parameters as a function of age of life and gestational age of the eight babies studied. Insignificant differences were found for all glycine dynamic parameters, pool size, and turnover rate constants between the different groups on the first day of life. Significant differences in rate constant of glycine disappearance were found between less and more mature preterm infants on the third day of life, although the pool sizes of the two groups were almost identical. Turnover rate constants were significantly $(P<$ 0.01 ) elevated in the more mature infants and as a result of these the fluxes in this group were significantly higher. At 3 to $4 \mathrm{wk}$ of life, statistically significant differences $(P<0.01)$ in pool size and turnover rate constants were obtained when compared to day of birth and 3 to 4 days of life. The pool size declined to $9.0 \pm 2.2$ $\mu$ moles/100 g body weight, whereas the turnover rate constant increased to $4.27 \pm 0.31 \mathrm{hr}^{-1}$, and the resulted fluxes remained unchanged.

Table 2. Urine glycine levels before and after $\left[\% \%{ }^{15} \mathrm{~N} / \mathrm{glycine}\right.$ administration

\begin{tabular}{lccc} 
& $\begin{array}{c}\text { Urinary glycine excre- } \\
\text { Subject }\end{array}$ & Afion $(\mu$ moles $/ \mathrm{hr})$ & $\begin{array}{c}\text { \% excess excretion of } \\
\text { administered glycine dose }\end{array}$ \\
\cline { 2 - 3 } & Before & After & \\
A. D.1 & 6.89 & 8.0 & 0.65 \\
A. D.2 & 11.50 & 13.20 & 1.06 \\
S. L.1 & 4.0 & 2.16 & 1.9 \\
S. L.2 & 3.84 & 5.69 &
\end{tabular}

' 1, first study: 2, second study. 
GLYCINE TURNOVER RATES AND POOL SIZES IN NEONATES

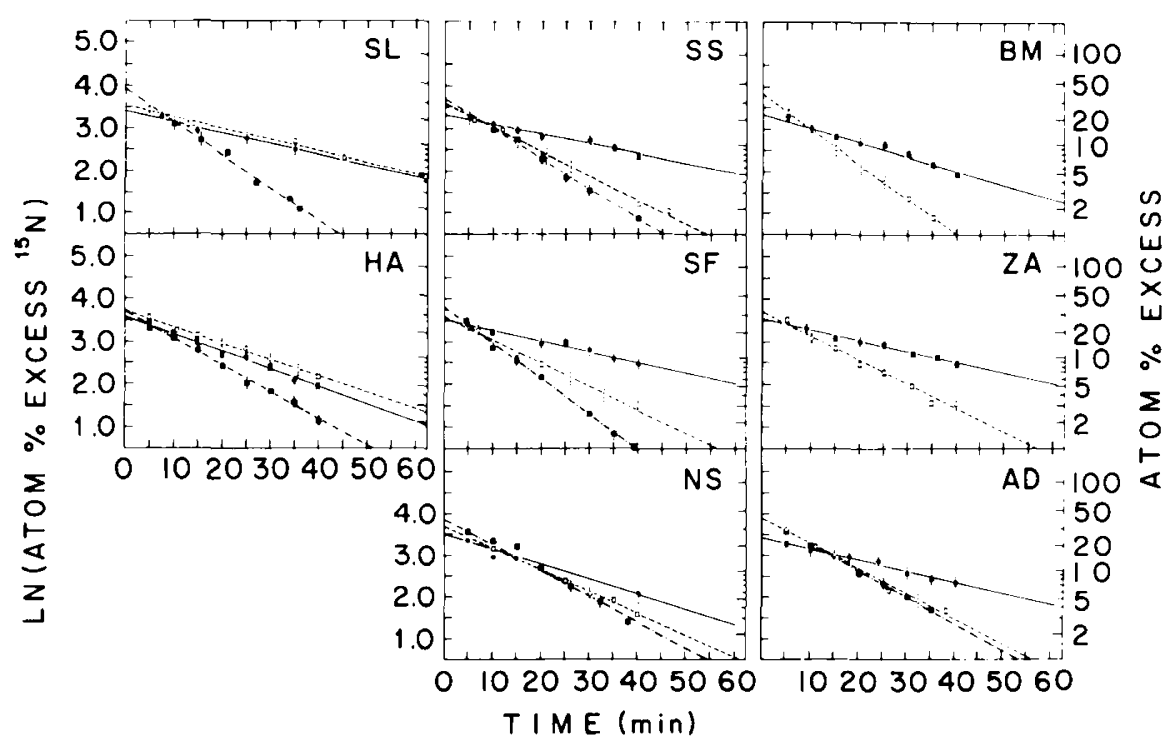

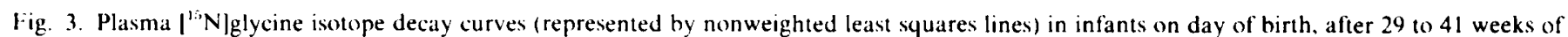
gestation. (O): 3 days old $(O)$ : and 3 to 4 wk old (
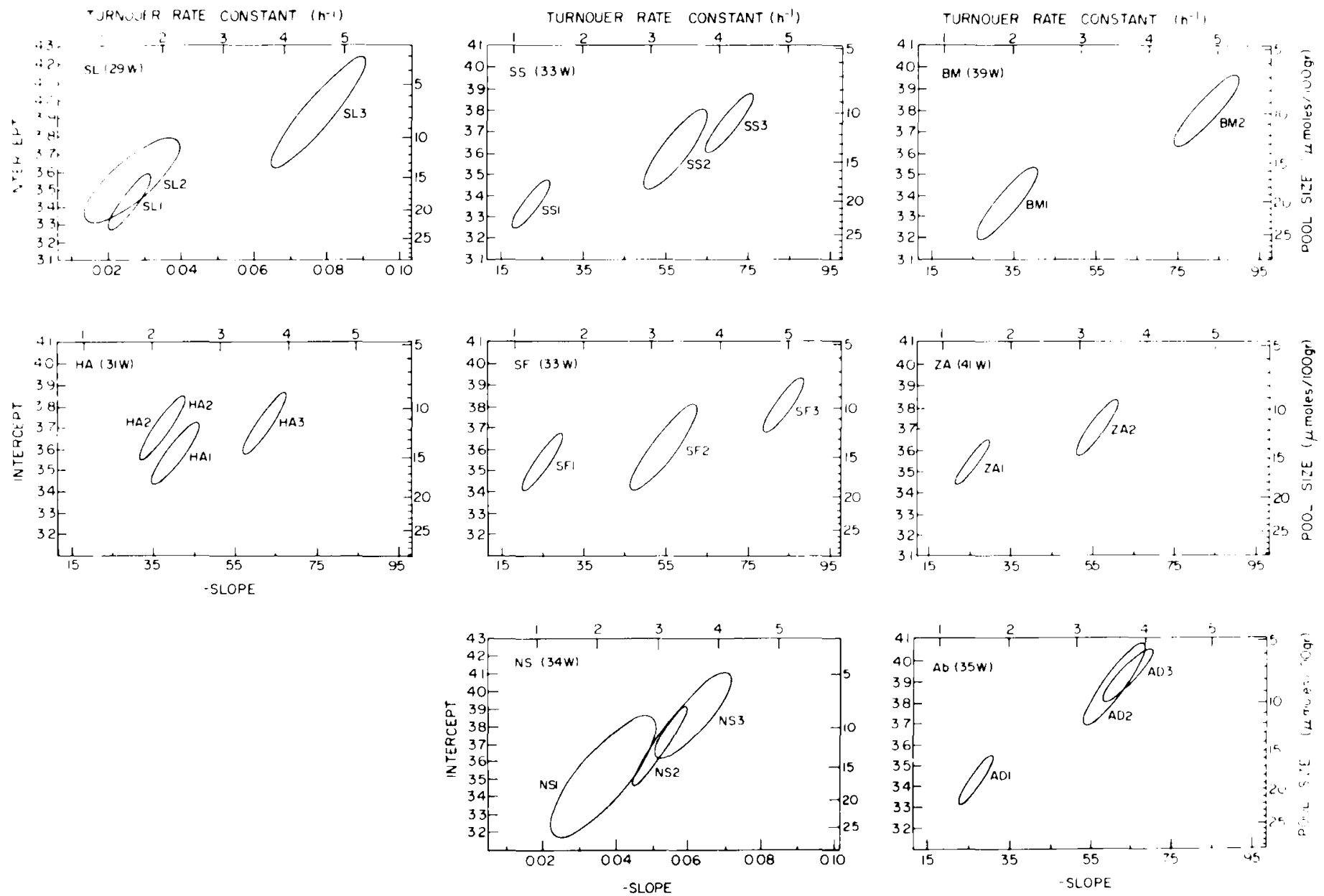

Fig. 4. Joint contidence region maps of glycine pool size and turnover rate constants of infants studied: $I$, on day of hirth after 29 to 41 wk of gestation: 2, 3 days old: and 3, 3 to 4 wk old.

\section{DISCUSSION}

This study makes use of a recently developed method $(15,18$, 26) with stable isotope and gas chromatography-mass spectrometry to determine the disappearance of labeled amino acids from plasma after IV administration of a single dose of $\left[{ }^{15} \mathrm{~N}\right]$ glycine in neonates. Inasmuch as this method makes use of natural substances labeled with nonradioactive stable isotopes, it qualifies as a low risk. repeatable. and accurate kinetic method directly applicable to studies in humans.

Recent studies in human volunteers $(17,19)$ revealed that plasma glycine disappearance curves over the first hr following a 
Table 3. Glycine kinetic parameters of preterm and full-term infants

\begin{tabular}{|c|c|c|c|c|}
\hline $\begin{array}{l}\text { Subjects and } \\
\text { study number }\end{array}$ & Pool ( $\mu$ mole $/ 100 \mathrm{~g}$ body wt) & $\begin{array}{l}\text { Turnover rate constant } \\
\text { (hr) }\end{array}$ & $P^{1}$ & Flux $(\mu$ moles $\mathrm{hr} 1 / \mathrm{I} 00 \mathrm{~g}$ body $\mathrm{wt})$ \\
\hline S. L. $1^{2}$ & $18.6 \pm 3.15^{.}$ & $1.56 \pm 0.26$ & & $28.9 \pm 3.24$ \\
\hline S. L. 2 & $15.6 \pm 3.86$ & $1.60 \pm 0.52$ & N.S.' & $24.1 \pm 7.99$ \\
\hline S. L. 3 & $7.95 \pm 3.76$ & $4.67 \pm 0.56$ & $<0.01$ & $35.4 \pm 18.8$ \\
\hline H. A.I & $14.7 \pm 2.56$ & $2.43 \pm 0.26$ & & $35.4 \pm 4.51$ \\
\hline H. A. 2 & $12.0 \pm 2.43$ & $2.25 \pm 0.25$ & N.S. & $26.5 \pm 3.86$ \\
\hline H. A.3 & $11.5 \pm 2.22$ & $3.74 \pm 0.24$ & $<0.02$ & $42.7 \pm 7.81$ \\
\hline S. F.I & $15.7 \pm 2.54$ & $1.51 \pm 0.22$ & & $23.5 \pm 2.10$ \\
\hline S. F.2 & $14.2 \pm 3.48$ & $3.27 \pm 0.36$ & $<0.01$ & $45.5 \pm 9.58$ \\
\hline S. F.3 & $9.86 \pm 1.76$ & $5.03 \pm 0.22$ & $<0.01$ & $49.3 \pm 9.34$ \\
\hline S. S.I & $20.5 \pm 2.50$ & $1.35 \pm 0.20$ & & $27.5 \pm 2.85$ \\
\hline S. S.2 & $13.8 \pm 3.17$ & $3.45 \pm 0.35$ & $<0.01$ & $47.1 \pm 9.57$ \\
\hline S. S.3 & $11.1 \pm 2.07$ & $4.25 \pm 0.26$ & $<0.01$ & $46.6 \pm 8.32$ \\
\hline N.S.I & $16.8 \pm 5.81$ & $2.10 \pm 0.56$ & & $36.3 \pm 11.8$ \\
\hline N. $S .2$ & $12.4 \pm 3.16$ & $3.13 \pm 0.29$ & $<0.05$ & $37.9 \pm 9.88$ \\
\hline N. S.3 & $9.05 \pm 3.25$ & $3.69 \pm 0.47$ & $<0.05$ & $32.3 \pm 11.70$ \\
\hline A. D.I & $18.6 \pm 2.40$ & $1.62 \pm 0.90$ & & $30 \pm 2.16$ \\
\hline A. D.2 & $8.56 \pm 2.53$ & $3.65 \pm 0.34$ & $<0.01$ & $30.5 \pm 9.09$ \\
\hline A. D. 3 & $7.72 \pm 1.57$ & $3.85 \pm 0.27$ & $<0.01$ & $29.4 \pm 5.61$ \\
\hline B. M.I & $20.6 \pm 3.78$ & $2.00 \pm 0330$ & & $41.1 \pm 4.62$ \\
\hline B. M.2 & $9.94 \pm 2.38$ & $4.93 \pm 0.36$ & $<0.01$ & $48.4 \pm 11.5$ \\
\hline Z. A. 1 & $15.6 \pm 1.92$ & $1.55 \pm 0.185$ & & $24.0 \pm 1.6$ \\
\hline Z. A. 2 & $11.9 \pm 2.06$ & $3.36 \pm 0.23$ & $<0.01$ & $39.5 \pm 6.1$ \\
\hline
\end{tabular}

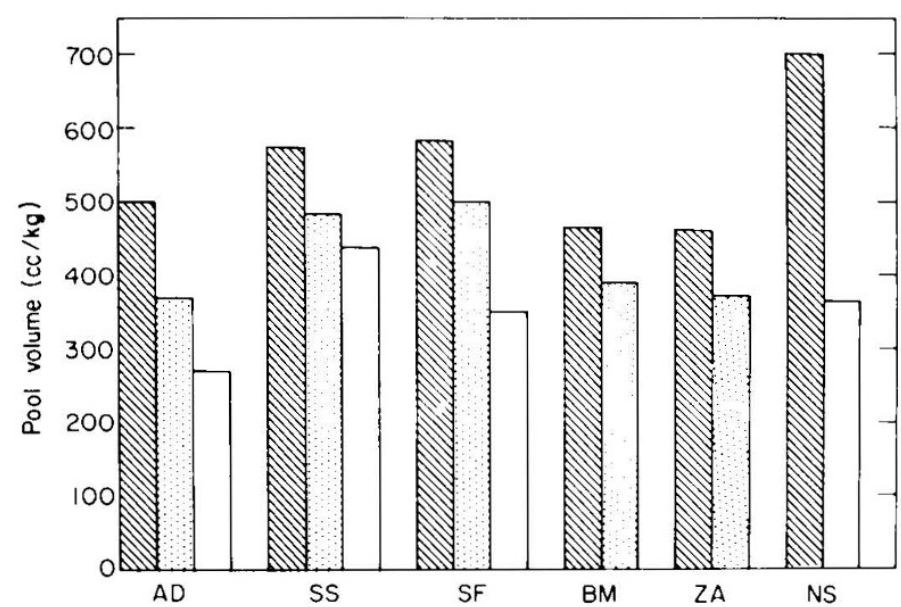

Fig. 5. Extracellular pool volumes (glycine pool size: glycine concentration) of preterm and full-term infants on day of birth. after 29 to 41

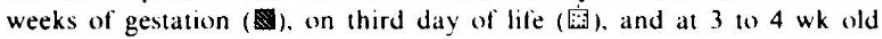
(口).

single IV dose of the labeled amino acid represents mainly the hepatic uptake of glycine from the extracellular pool. This assumption is based on the recent finding in rabbits (26) showing that the amount of glycine removed from the circulation compares well with the rate of uptake of plasma glycine by the liver (12).

Flux (into the liver) was calculated in healthy volunteers (17) to be 21.8 to $33.5 \mu$ moles min $1 / 100$ g liver tissue which is similar to those obtained by direct measurement in rabbits (26).

In this study, the volume of glycine pool varied from the day of birth to 4 wk of life. Mean values of $500 \mathrm{ml} / \mathrm{kg}$ body weight at day of birth to $350 \mathrm{ml} / \mathrm{kg}$ body weight at the age of 3 to $4 \mathrm{wk}$ of life are compatible with the extracellular volumes found in neonates at this age $(5,16)$.

The equilibration of labeled amino acid with the extracellular pool (Fig. 1) was found to be completed within $5 \mathrm{~min}$ and did not introduce any difficulties in steady-state kinetic analysis.

Although relatively large doses of $\left[{ }^{1 . i} \mathrm{~N}\right]$ glycine were administered, no evidence for overloading or nonsteady state kinetics was found because disappearance curves were linear (Fig. 3) and plasma glycine levels were relatively constants (Fig. 1). No significant differences were observed in glycine kinetic parameters (pool sizes or rates of disappearance) when glycine dose was reduced to one-half $(46.6 \mu$ moles $/ \mathrm{kg})$ in human subjects studied (17) or in parailel tracer experiments in rabbits used $\left[{ }^{14} \mathrm{C}_{2}\right]$ glycine, when $\left[{ }^{14} \mathrm{C}_{2}\right]$ glycine was administered with and without an equal amount of nonlabeled glycine as in the ${ }^{15} \mathrm{~N}$ tracer experiments (26).

No evidence of any trace of $\left[{ }^{1} \mathrm{~N}\right]$ glycine was found in the urine of the infants following the IV administration of [ $\left.{ }^{15} \mathrm{~N}\right]$ glycine.

The kinetic parameters observed in a group of preterm and term infants revealed significant differences in values obtained corresponding to days of life and gestational age. Pool size of 14.7 to $20.6 \mu$ moles $/ 100 \mathrm{~g}$ body weight found on day of birth were very significantly different $(P<0.01)$ from any pool size obtained at the age of 3 to $4 \mathrm{wk}$ of life in preterm infants or 3 to 4 days after birth in term infants $(7.71011 .9 \mu$ moles $/ 100 \mathrm{~g}$ body weight). The latter values of pool sizes are similar to those found in adult humans (17).

The significant reduction in pool sizes during the first days of life is probably related to the diminished plasma glycine levels ( 2 . $24.34)$ and the decreased extracellular volume in preterm infants during their first days of life $(5,16)$.

The disappearance rate constants of glycine from the circulation in neonates change dramatically during the first month of life. A 2 to 3 -fold increase in rate constants were found after 3 to $4 \mathrm{wk}$ of life in comparison to values obtained on the day of birth. The most significant changes occur already after 3 to 4 days of life. except in the two smallest preterm infants (S. L. and A. L.). Rate constants at the age of 3 to $4 \mathrm{wk}$ of life were similar to those obtained in normal adults (17).

The biochemical and physiologic explanation for the changes in glycine turnover rates during the neonatal period is speculative. 
Table 4. Variations of glycine dinamic parameters as a function of age

Groups and numbers of subjects
Pool

( $\mu$ moles/lo0) g body wt)

$18.0 \pm 2.1$
$13.3 \pm 2.2$
$13.1 \pm 2.5$
$9.0 \pm 2.2$
Turnover rate constant

(hr ')

$1.68 \pm 0$.

$2.07 \pm 0.24$

$3.43 \pm 0.28$

$4.27 \pm 0.31$
Flux

( $\mu$ moles hr $1 / 10 \mathrm{~g}$ body wt)

$30.2 \pm 2.0$
$27.4 \pm 3.1$
$44.3 \pm 7.2$
$37.8 \pm 8.9$

$C(n=4)$

$\mathrm{D}(n=6)$

A. all infants on day of birth: B, 3-day-old preterm infants after 29 to 31 wk of gestation. C, 3-day-old preterm infants after 33 to 35 wk of gestation: D, 3 to 4 wk old, all preterm infants.

2 Mean \pm S.D.

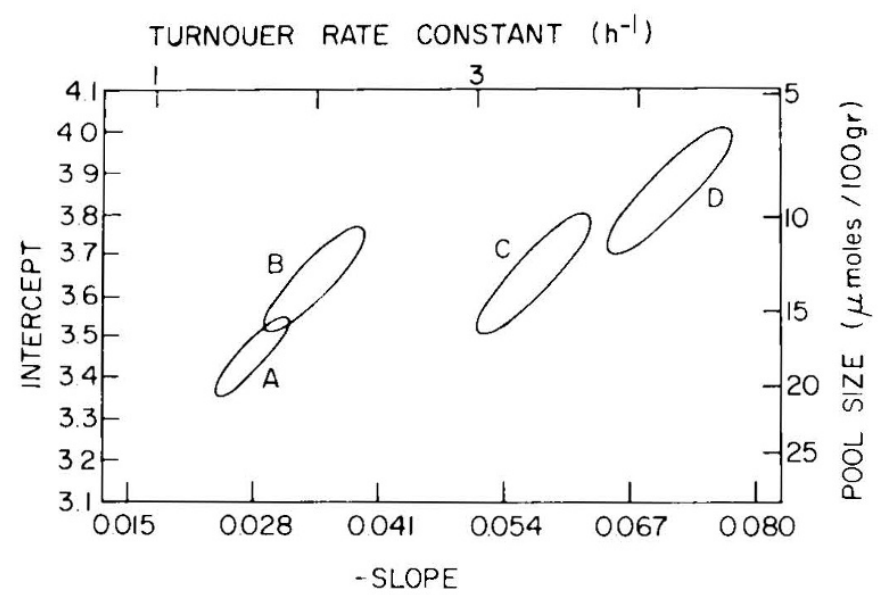

Fig. 6. Summary of glycine dynamics in preterm and full-term infants. $A$. all infants on day of birth: $B, 3$-day-old preterm infants after 29 to 31 wk of gestation: $C, 3$-day-old preterm infants after 33 to 35 wk of gestation: $D$, all preterm infants at 3 to $4 \mathrm{wk}$ old.

Factors such as enzyme maturation. hormonal activities, and transport mechanisms probably affect the dynamic parameters of amino acids (glycine) metabolism after birth. It is well known that after birth some metabolic processes are impaired as a result of immaturity of enzyme systems $(4,10,22,35,42)$. This might explain the reduced uptake of glycine into the liver. The hormonal activities of insulin, glucagon, and growth hormone were found to change rapidly after birth $(1,11,34)$, which might explain their effect on amino acid transport and metabolism. It was found that hypoaminoacidemic response to pharmacologic dose of glucagon in newborn infants on the third day of life resembles the response in adults but is attenuated on the day of birth (34). Inadequate liver transport mechanism which limits sulfobromophthalein sodium $(28,43)$ or bilirubin excretion $(6,44)$ may also effect glycine rates of uptake into the liver.

The study of the metabolism of individual amino acids in the neonatal period is most important in view of the markedly increased use of parenteral nutrition. We have shown in this study that there are significant differences in the dynamic parameters of IV administered labeled glycine during the first wk of life in both preterm and term infants. By the age of 3 to $4 \mathrm{wk}$, all these infants now showed similar kinetic data as in adults. Further studies are now in progress with other individual amino acids.

\section{REFEREN(ES AND NOTES}

1. Cornblath. M.. Parker. M. L., Reisner. S. H.. Forbes, A. E., and Daughaday. W $H$.: Secretion and metabolism of growth hormone in premature and full-term infants. J. ( Clin. Endocrinol. Metah., 25: $209(1965)$.

2. Dickinson. J. C.. Rusenblum. H.. and Hamiloon. P. B.: Ion exchange chromatog. raphy of the free amino acids in the plasma of infants under $25(0)$ grams of birth. Pediatrics, 45: $606(1970)$.

3. Dubovitz. L. M. S.. Dubovitz. V., and (joldherg. ( .: Clinical assessment of gestational age in the newborn infant. J. Pediatr.. $? ?: 1$ (1970).

4. Felsher, B. F., Carpio, N. M., Wooley, M. M.. and Assh. M. J.: Hepatic biliruhin glucoronidation in neonates with unconjugates hyperhilirubinemia and congenital gastrointestinal obstruction. J. L.ah. ( Clin. Med.. \&.8: 90) (1974).
5. Friis-Hansen. B.: Body compositwn during grouth. Pediatrics. $f^{+}: 264$ (1971).

6. Gartner. L. M.. and L.ane. D.: Hepatic metabolism and transport of hilirubin during physiologic jaundice in the newborn rhesus monkey. Pediatr. Res.. 5: 43 (1971).

7. Gehrke, ( . W., Kuo, K. and Zumwalt. R. W.: The complete gas-liquid chromatographic separation of the twenty amino acids. J. ('hromatogr.. 5-: 2114 (1971)

x. Ghadimi. H.. Abaci. F. and Kumar. S.: Bicchemical aspects of intravenous alimentation. Pediatrics, 4s: $455(1971)$.

9. Gordon. A. H.. and Ford. R. A.: The Chemist's Companion. p. $4 \times 7$ (John Wiley \& Sons. Inc.. New York. 1972)

10. Gaull. (;.. Sturman. J. A.. and Raiha. N. C. R.: Development of mammalian sulfur metabolism: absene of eystathionase in human fetal tissues. Pediatr. Res., 0: 538 ( 1972$)$

11. Grasso. S.. Saporito, N., Messina. A.. and Reitano. (i.: Serum insulin response 10 glucose and amino acids in the premature infant. l.ancet. $2: 755(1968)$.

12. Henriques, O. B.. Henriques, S. B.. and Neuberger. A.: Quantitative aspects of glycine metaholism in the rabbit. Biochem. J.. of): $4(1) 9$ (1955).

13. Hittmer. H. M.. Hirsh. N. J.. and Rudolph. A. S.: Assessment of gestational age by examination of the anterior vascular capsule of the lens. J. Pediatr.. 41: 455 (1977).

14. Irving. (. S.. Nissim. 1., and L.apidot. A.: Whole body amino acids pools and turnover rates determined by stable isotope gas-chromatographic-mass-spectrometric methodology. Monogr. Hum. (ienet.. 9: 50 (197x).

15. Irving, ( . S.. Nissim. I.. and L.apidot. A.: The determination of amino acid pool sizes and turnover rates by gas-chromatographic-mass psectrometric analysis. Biomed. Mass Spectrom.. 5: 117 (1978).

16. Kagan. P. M.. Stanincova. V.. Felix. M. S.. Hodgman. J.. and Kalman. D.: Body composition of premature infants. relation to nutrition. Am. J. ( lin. Nutr.. 25: $1053(1972)$.

17. Lapidot. A.. and Nissim. 1.: Regulation of pool size and turnover rates of amino acids in humans: ${ }^{15} \mathrm{~N}$-glycine and ${ }^{15} \mathrm{~N}$-alanine single dose experiments using gas chromatography-mass spectrometry analysis. Metabolism 29: 230 (1979).

18. Lapidot, A., Nissim. I., and Irving, C. S.: The diurnal rhythms in plasma amino acid pool sizes and turnover rates measured by gas chromatographic-mass spectrometric analysis of stable tracer ${ }^{15} \mathrm{~N}$-glycine. Isr. J. Chem. Soc., 77: 209

19. Lapidot. A.. Nissim. I.. Irving. (. S.. Liberman. U. A.. and Samuel. R.: Stable isotope. Proceeding of the Third International conference. pp. 599 6ity (Academic Press. Inc.. New York. 1979)

20. Lapidot. A.. Nissim. I., Shahali. M.. Samuel. R.. and Liberman. A.: Dynamic aspects of glycine pools and turnover rates in leukemia patients using stable isotopes. Submitted for publication.

21. Lark. P. D.. Craven. B. R.. and Bosworth. R. ( . L.: The handing of chemical data. pp. $142 \cdot 153$ (Pergamon Press. Lid.. Oxtord. 1968).

22. Lathe. (j. H.. and Walker. M.: The synthesis of hilirubin glucoronide in animal and human liver. Biochem. J.. 7): 705 (195x).

23. Lindblad. B. S.. Alfien. (i., and Zetterstrom. R.: Plasma free amino acid concentration of breast-fed infants. Acta Paediatr. Scand.. $0^{-7}$ : $659(147 \times)$.

24. Lindblad, B. S., and Baldesten. A.: Time studies on free amino levels of venous plasma during the neonatal period. Acta Paediatr. Scand.. $55 x$ : 252 (1969).

25. Munro, H. N.: Free amino acid pools and their regulation. In: H N. Munro: Mammalian Protein Metabolism. Vol. 4. pr. $2993 \times 7$ 1Academic Press. Inc.. New York. 197(0).

26. Nissim, I.. and Lapidot, A.: Plasma amino turnover rates and pools in rabbits, in vivo studies using stable isotopes. Am. J. Physiol.. 237: E418 (1979).

27. Nyhan, W. I.. and Childs, B.: Hyperglycinemia. V. The miscible pool and turnover rate of glycine and the formation of serine. J. Clin. Invest., 43: 2404 (1964).

2x. Obrinsky, W.. Denley. M. 1... and Brauer. R. W.: Soltobromophtalein sodium excretion test. as a measure of liver function in premature infants. Pediatrics. y: $421(1952)$.

24. Penchars. P. B.. Stetee. W. P.. Cuchran. W.. Scrimshaw, N. S.. Rand. W. M... and Young. V. R.: Protein metaholism in human neonates. Nitrogen-balance studies, estimated obligatory losses of nitrogen and whole-body turnover of nitrogen. ( lin. Sci. Mol. Med., 52: 485 (1977).

30. Picou. D.. and Taylor-Roherts. T.: The measurement of total protein synthess and catabolism and nitrogen turnover in infants in different nutritional states and receiving different amounts of dietary protein. (Clin. Sci. (Oxf.). 3n: $2 \times 3$ (1969).

31. Pohlandi. F.: Zur vermedug van Aminosauren imbalonzen bes Neugeborenen mit parenteroler Ermahurng. Monatsschr. Kinderheilkd.. 12.3: 448 (1975). 
32. Pohzandt. F.: Plasma amino acid concentrations in newborn infants breast-fed ad lihitum. J. Pediatr.. "2?: 616(197x).

33. Rassin. D. K.. (iaull. (j. E.. Heinonen. K.. and Raihha. N. R. ( .: Milk protein quantity and quality in low birth weight infants. II. Effects on selected aliphtic amino acids in plasma and urine. Pediatrics. 51): 4077 (1977).

34. Reisner. S. H.. Aranda. J. V.. Colle. E.. Papageorgiou. A., Schift. D.. Scriver. C R.. and Stern. L.: An effect of intravenous glucagan on plasma amino acids in the newborn. Pediatr. Res.. $\because$ I 84 (1973).

35. Rigo. J.. and Sentrerre. J.: Is taurine essential for the neonates? Biol. Neonate. 3.: 73 (1977).

36. Roach. D., and (iehrke. C. W.: Direct esterification of the protein amino acid gas-liquid chromatography of N-TFA n-hutyl Fsters. J. (hromatogr.. 44: 269 (1969).

37. Sardesai. V. N.. and Provido, H. S.: The determination of glycine in biological tluids. Clin. Chim. Acta. 24: 67 (1970)

3x. Schulman. M. F.. and Abramson. F. P.: Plasma amino acid analysis by isotope ratio gas chromatography mass spectrometry computer techniques. Biomed. Mass Spectrom.. 2: 9 (1975)

39. Shoenheimer, R., and Ratner. S.: Studies in protein metabolism. II. Synthesis of amino acid containing isotopic nitrogen. J. Biol. ( hem.. 127: 30) (1938).

40. Snyderman. S. E.. Holt. L. F... Jr.. Norton. P. M.. Roitman. E.. and Phansalkar. S. V.: The plasma aminogram. Influence of the level of protein intake and comparison of whole protein and amino acid diets. Pediatr. Res.. 2: 131 (1968).

41. Stein. T. P.. Jeskin. M. J.. and Wallace. W.: Eyulibration of ${ }^{\prime} \mathrm{N}$ labelled amino compound in man. Am. J. Physiol., 2311: 1,326 (1976).

42. Sturnman. J. A.. (iaull. (i.. and Raiha. N. C. R.: Absence of cystothionaze in human fetal liver is cystine essential"? Science (Wash. D( ). 10\%. 74 (1970)

43. Sussman, S., Carbone, J. V.. Grodsky, G., Hjelet, V., and Miller, P.: Sulfobrom ophtalein sodium metabolism in newborn infants. Pediatrics, 29: 899 (1962).

44. Thaler, M. M., and Schmid. R.: Drugs and bilirubin. Pediatrics, 47: 807 (1971).

45. Usher, R.. and Mclean. F.: Intrauterine growth of live-born Caucasian infants a sea level standards obtained from measurement in 7 dimensions of infants born between 25 and 44 weeks of gestation. J. Pediatr., 74: 901 (1969).

46. Waterlow. J. ( .: Protein Nutrition and Metabolism in the Whole Animal. In: H N. Munro: Mammalian Protein Metabolism. Vol. 3. pp. 326.390 (Academic Press. Inc.. New York. 1969).

47. Young. V. R.. Steffee. W. P.. Pencharz. P. B.. Winterer. T. (... and Schrimshaw. N. S.: Total human body protein synthesis in relation to protein requirements at various ages. Nature (Lond.). 25.3: 192 (1975).

4x. We acknowledge the generous supply of $\mathrm{H}^{\prime} \mathrm{NO}$, proivided to use by the lsotope Separation Plant of The Weizmann Institute and the help in ( $)$ (-MS analysis of 1 . Nissim

49. Requests for reprints should he addressed to: Dr. Aviva. Lapidot. Isotope Department. The Weizmann Institute of Science. Rohovot. Israel.

50. This research was supported in part by a grant from Israel Ministry of Health (o) Aviva Lapidot.

51. Received for publication November 20. 1979.

52. Accepted for publication February 1. 1980)

Copyright (C) 1980 International Pediatric Research Foundation, Inc. $0031-3998 / 80 / 1411-1238 \$ 02.00 / 0$ 